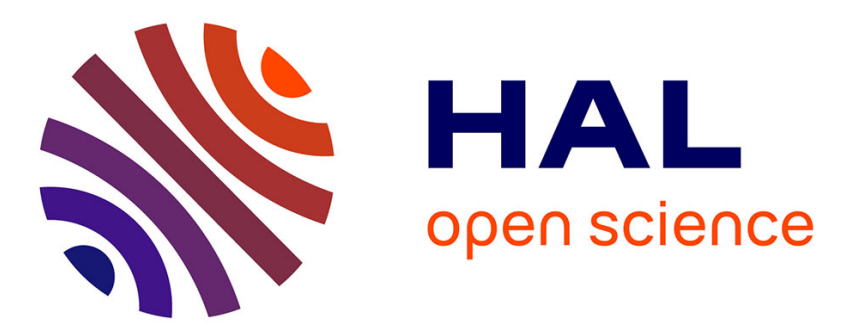

\title{
Comparison of ochratoxin A and deoxynivalenol loads of organically and conventionally produced beers sold on the Belgian market
}

Emmanuel Kossi Tangni, Luc Pussemier, Jean Claude Motte, François van Hove, Yves Jacques Schneider, Carlos van Peteghem, Yvan Larondelle

\section{To cite this version:}

Emmanuel Kossi Tangni, Luc Pussemier, Jean Claude Motte, François van Hove, Yves Jacques Schneider, et al.. Comparison of ochratoxin A and deoxynivalenol loads of organically and conventionally produced beers sold on the Belgian market. Food Additives and Contaminants, 2006, 23 (09), pp.910918. 10.1080/02652030600743839 . hal-00577299

\section{HAL Id: hal-00577299 \\ https://hal.science/hal-00577299}

Submitted on 17 Mar 2011

HAL is a multi-disciplinary open access archive for the deposit and dissemination of scientific research documents, whether they are published or not. The documents may come from teaching and research institutions in France or abroad, or from public or private research centers.
L'archive ouverte pluridisciplinaire HAL, est destinée au dépôt et à la diffusion de documents scientifiques de niveau recherche, publiés ou non, émanant des établissements d'enseignement et de recherche français ou étrangers, des laboratoires publics ou privés. 


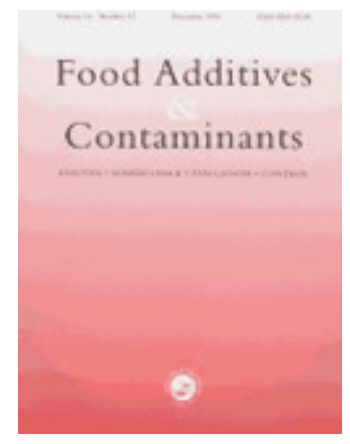

\section{Comparison of ochratoxin A and deoxynivalenol loads of organically and conventionally produced beers sold on the Belgian market}

\begin{tabular}{|r|l|}
\hline Journal: & Food Additives and Contaminants \\
\hline Manuscript ID: & TFAC-2006-022.R2 \\
\hline Manuscript Type: & Original Research Paper \\
\hline Author: & 05-Apr-2006 \\
\hline Complete List of Authors: & $\begin{array}{l}\text { TANGNI, Emmanuel; Veterinary and Agrochemical Research Center, } \\
\text { Quality and Safety } \\
\text { Pussemier, Luc; Veterinary and Agrochemical Research Center, } \\
\text { Quality and Safety } \\
\text { Motte, Jean Claude; Veterinary and Agrochemical Research Center, } \\
\text { Quality and Safety } \\
\text { Van Hove, François; Université catholique de Louvain, Mycothèque } \\
\text { de I'Université catholique de Louvain (BCCMTM/MUCL) } \\
\text { Schneider, Yves Jacques; Université catholique de Louvain, } \\
\text { Laboratoire de biochimie cellulaire, Institut des Sciences de la Vie } \\
\text { Van Peteghem, Carlos; Ghent University, Laboratory of food } \\
\text { analysis, Faculty of Pharmaceutical Sciences } \\
\text { Larondelle, Yvan; Université catholique de Louvain, Unité de } \\
\text { biochimie de la nutrition }\end{array}$ \\
\hline Methods/Techniques: & $\begin{array}{l}\text { Chromatography - HPLC, Clean-up - affinity columns, Exposure } \\
\text { assessment, In-house validation }\end{array}$ \\
\hline Additives/Contaminants: & Mycotoxins - trichothecenes, Mycotoxins - ochratoxin A \\
\hline Food Types: & Beer, Organic foods, Processed foods \\
\hline & \\
\hline
\end{tabular}




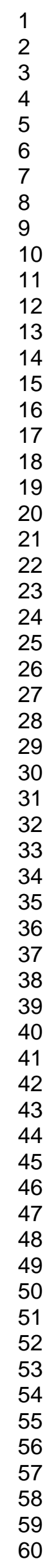

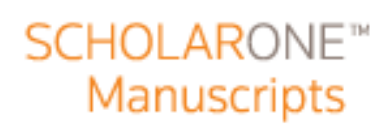

7

25

26

27

29

30

32

33

34

35

36

37

39

40

41

42

44

45

46

47

48

49

51

52

54

55

57

58

59

60

http://mc.manuscriptcentral.com/tfac Email: fac@tandf.co.uk 


\title{
Comparison of ochratoxin A and deoxynivalenol in organically and
}

\section{conventionally produced beers sold on the Belgian market}

\author{
ANSELME M. ${ }^{1}$, TANGNI E.K ${ }^{2, *}$, PUSSEMIER L ${ }^{2}$, MOTTE J-C ${ }^{2}$, VAN HOVE $^{3}$, SCHNEIDER \\ $\mathrm{Y}^{-\mathrm{J}^{4}}$, VAN PETEGHEM $\mathrm{C}^{5} \&$ LARONDELLE $\mathrm{Y}^{1}$ \\ ${ }^{1}$ : Unité de biochimie de la nutrition, Institut des Sciences de la Vie, Université catholique de \\ Louvain, Croix du Sud 2/8, 1348 Louvain-la-Neuve, Belgium \\ 2: Department of quality and safety, Veterinary and Agrochemical Research Centre (CODA- \\ CERVA), Leuvensesteenweg, 17, B-3080 Tervuren, Belgium \\ 3: Mycothèque de l'Université catholique de Louvain $\left(\mathrm{BCCM}^{\mathrm{TM}} / \mathrm{MUCL}\right)$, Unité de Microbiologie, \\ Croix du Sud 3/6, 1348 Louvain-La-Neuve, Belgium. \\ ${ }^{4}$ : Laboratoire de biochimie cellulaire, Institut des Sciences de la Vie, Université catholique de \\ Louvain, Croix du Sud 5/3, 1348 Louvain-la-Neuve, Belgium. \\ 5: Laboratory of food analysis, Faculty of Pharmaceutical Sciences, Ghent University, \\ Harelbekestraat 72, 9000 Ghent
}

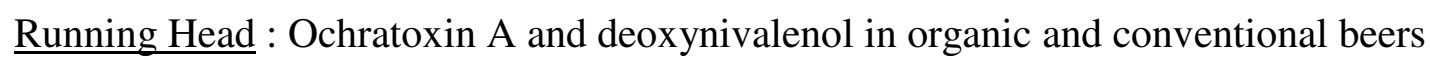

\footnotetext{
*: Correspondence: E. K. Tangni, E-mail: emtan@var.fgov.be
} 
Beer was chosen as a cereal-derived and homogeneous product which would allow a comparison to be made of organic and conventional production modes in terms of mycotoxin contamination levels. Ochratoxin A (OTA, a storage mycotoxin) and deoxynivalenol (DON, a field mycotoxin) were assessed by HPLC methods in organically and conventionally produced beers sold in Belgium. Immunoaffinity column (OchraTest ${ }^{\circledR}$ and DONPrep ${ }^{\circledR}$ ) purification was used prior to HPLC analysis. For in-house validation, recovery experiments carried out with the spiked beers in the ranges of $50-200 \mathrm{ng}$ OTA $\mathrm{l}^{-1}$ and $20-100 \mu \mathrm{g}$ DON $\mathrm{l}^{-1}$ led to the overall averages of $91 \%(\mathrm{RSD}=$ $10 \%, \mathrm{n}=9)$ and $93 \%(\mathrm{RSD}=5 \%, \mathrm{n}=27)$, respectively. Organic beers collected during 2003-2004 tended to be more frequently OTA contaminated $(95 \%, \mathrm{n}=40)$ than their conventional counterparts $(50 \%, \mathrm{n}=40)$. Conventional beers were OTA contaminated at a mean concentration of $25 \mathrm{ng} \mathrm{l}^{-1}$ (range: 19 - $198 \mathrm{ng} \mathrm{l}^{-1}$ ) whilst organic beers contained a mean level of $182 \mathrm{ng} \mathrm{l}^{-1}$ (range: $18-1134 \mathrm{ng} \mathrm{l}^{-1}$ ). High OTA contamination above the limit of $200 \mathrm{ng} \mathrm{l}^{-1}$ (up to $1134 \mathrm{ng} \mathrm{l}^{-1}$ ) occasionally occurred in organically produced beers. A complementary survey performed with the same brands in 2005 did not confirm this accidental presence of excessive OTA loads (range: 3 - 67 $\mathrm{ng} \mathrm{l}^{-1}$ for 10 conventional beers and $19-158 \mathrm{ng} \mathrm{l}^{-1}$ for 10 organic beers). Establishing a maximum of $3 \mu \mathrm{g} \mathrm{OTA} \mathrm{kg}^{-1}$ in malt, the application of the regulation EC 466/2001 (entered in force before the last sampling) may be related to the improvement observed. The overall incidence of DON was 67 and $80 \%$ in conventional and organic beers, respectively. DON concentrations ranged from 2 to 22 $\mu \mathrm{g} \mathrm{DON}^{-1}$ (mean $\left.=6 \mu \mathrm{g} \mathrm{DON}^{-1}\right)$ in conventional beers whilst organic beers were contaminated from 2 to $14 \mu \mathrm{g} \mathrm{DON}^{-1}$ (mean $=4 \mu \mathrm{g} \mathrm{DON}{ }^{-1}$ ). DON in beers does thus not appear to be a major matter of concern. From the statistical tests, it could be concluded that the variation between different batches was significant $(\mathrm{p}<0.0001)$ in contrast to that observed between different brands, showing thus a lack of homogeneity in the raw materials. This may occur either in organically or in conventionally produced materials. Considering these results, an optimized frequency of controls according to European Regulations EC No 466/2001 and EC No 856/2005 should be recommended in order to reject the irregular batches.

Keywords : Food safety, mycotoxin, ochratoxin A, deoxynivalenol, beer, organic, conventional, Belgium. 


\section{Introduction}

Due to food crises in the recent past, organic food products have become more popular in Belgium and elsewhere (Pussemier et al. 2006). Indeed, the demand for organic foods is constantly increasing mainly due to the consumers' perception that they are healthier and safer than conventional foods (Magkos et al. 2003). The situation may however be more complex. Some authors indicate that organic food often contains relatively high amounts of natural toxic compounds produced by fungi or plants, whereas corresponding conventional food tends to contain more synthetic compounds such as pesticide residues (Finamore et al. 2004). By contrast, Pussemier et al. (2006) have concluded that the influence of organic cultivation methods on the presence of natural toxins is not yet clear. In terms of mycotoxins, even though the foodstuffs resulting from conventional production are not free of mycotoxins, the organic foodstuffs may present a greater risk of contamination. So, there is a need for information related to food safety to inform the consumers of the health benefits and/or hazards of food products of both origins, in order to optimize the impact on health and minimize the risks.

The mycotoxin ochratoxin A (OTA) has strong nephrotoxic, immunosuppressive and teratogenic properties. Its worldwide occurrence as a contaminant of raw agricultural products has been amply documented in a variety of plant products such as cereals, coffee, dried fruits, cocoa, grapes and spices (MacDonald et al. 1999, 2004, Otteneder \& Majerus 2001, Serra et al. 2005, Thirumala-Devi et al. 2001). Mainly produced by toxigenic strains of the genera Aspergillus and Penicillium (Pitt 1987, Moss 1998, Samson et al. 2004), high OTA levels mainly occur in stored products. Before storage, cereals are prone to be contaminated in the field by fungi of different Fusarium species. These fungi may infect the plant and produce trichothecenes, with deoxynivalenol (DON) being the most abundant representative one in cereal grains (Boeira et al. 2000). Thus, malting barley, wheat and corn, which are used in brewing either as main ingredients or as adjuncts, can be contaminated by OTA and/or DON. So far, a handful studies have investigated the fate of these mycotoxins 
during malting, brewing and fermentation and they have concluded that OTA and DON can at least partially withstand these complex food processing and, finally, may remain present in beer (Niessen \& Donhauser 1993, Baxter 1996, Baxter et al. 2001, Papadopoulou-Bouraoui et al. 2004). Beer is thus a convenient cereal-derived foodstuff allowing to compare the organic and conventional production modes in terms of mycotoxin contamination levels. To our knowledge, the influence of the organic route of beer production on the presence of natural toxins, such as OTA and DON, has not been yet studied. Therefore, the present investigation was initiated to compare the OTA and DON contaminations in organic and conventional beers produced in Belgium, the European country with the greatest diversity of beers. The study includes the development of a method for the determination of DON in beer using immunoaffinity clean-up coupled with HPLC-UV detection.

\section{Materials and methods}

\section{Sample collection and handling}

Keeping, as far as possible, a balance between organic and conventional products, forty conventionally produced beers (representing 10 brands) and forty organically produced beers (representing 10 brands) were randomly purchased in the supermarkets and retail shops in Belgium from September 2003 to September 2004. All these brands were manufactured in Belgium. To ensure some variation in batches and brands of the sampled materials, two batches per brand and two samples per batch were tested. A complementary sampling was performed on the same brands (10 conventional and 10 organic beers) in March 2005 to check the temporal fluctuation in OTA contamination, especially for previously high OTA contaminated brands. Here, one bottle (one batch) of each brand was investigated. All samples were stored at $4^{\circ} \mathrm{C}$ till opening for analysis.

\section{Reagents and materials}

Pure crystalline forms of OTA and DON were obtained from Sigma Chemical Co. (St Louis, MO, USA). The stock solution of OTA was made in toluene:acetic acid (99:1) whereas that of DON was 
made in acetonitrile far-UV (of HPLC grade). The concentrations were determined by spectrophotometry (Wood et al. 1996, Petterson 1998). The stock solutions were stored at $-18^{\circ} \mathrm{C}$ until re-use (maximum storage duration of 12 months).

OTA and DON immunoaffinity columns $\left(\right.$ OchraTest $^{\circledR}$ and DONPrep $\left.{ }^{\circledR}\right)$ were obtained from Vicam (Watertown, MA, USA) and from R-Biopharm (Rhône diagnostics Ltd, Glasgow, Scotland), respectively. Microfilters type Millex ${ }^{\circledR}-\mathrm{HV}$, SLHV R04NL $(0.45 \mu \mathrm{m})$ and Durapore ${ }^{\circledR}$ membrane filters (type $0.22 \mu \mathrm{m} \mathrm{GV}$, GVWP04700) were purchased from Millipore (Bedford, MA, USA).

Acetonitrile and toluene of HPLC grade were supplied by Lab Scan (Dublin, Ireland). Methanol of HPLC grade and acetic acid pro analysis were obtained from Acros Organics (New Jersey, NY, USA) or from Biosolve (Valkenswaard, The Netherlands) while hydrochloric acid (37\%) was purchased from Riedel-de Haën (Seelze, Germany). Phosphate-buffered saline (PBS) solution ( $\mathrm{NaCl} 120 \mathrm{mM}, \mathrm{KCl} 2.7 \mathrm{mM}$, phosphate buffer $10 \mathrm{mM}$, pH 7.4) was supplied by Sigma. Sodium bicarbonate $\left(\mathrm{NaHCO}_{3}\right)$ was supplied by Merck (Darmstadt, Germany). All other chemicals were of analytical grade.

HPLC grade water was obtained using a twin system composed by Elix3 and Milli-Q system, both from Millipore (Molsheim, France).

Helium of $99.996 \%$ purity and nitrogen of $99.995 \%$ purity were provided by Air Liquide (Liège, Belgium).

\section{OchraTest method for OTA determination in beer}

OTA determination in beer was performed according to the method described by Tangni et al. (2002). First, bottles of beer were vigorously shaken and left for $10 \mathrm{~min}$ before opening. A sample of beer was taken and decarbonated by shaking again for $10 \mathrm{~min}$. Degassed beer $(40 \mathrm{ml})$ were then diluted with water $(5 \mathrm{ml}$, containing $4 \%(\mathrm{w} / \mathrm{v})$ sodium bicarbonate) and with PBS solution (15 ml). Solid particles were separated by centrifugation of the mixture at $820 \mathrm{xg}$ during $10 \mathrm{~min}$ at $8 \pm 2^{\circ} \mathrm{C}$. 
The supernatant $(45 \mathrm{ml})$ were used for the next steps. Clean-up of the OTA extract was performed with an OchraTest column fitted with a 20-ml syringe reservoir and placed on a vacuum manifold. Before loading the extract, the OchraTest column was conditioned with $20 \mathrm{ml}$ of PBS solution (pH 7.4). The OTA extract was passed through the column at about 1-2 $\mathrm{ml} \mathrm{min}^{-1}$. De-ionized water (20 $\mathrm{ml}$ ) was used to wash the loaded immunoaffinity column and OTA was eluted with methanol (2 ml) and de-ionized water ( $2 \mathrm{ml})$. Atmospheric air ( $c$ a $20 \mathrm{ml}$ ) was passed through the column to collect all the eluate. The solution was stored at $-20^{\circ} \mathrm{C}$ prior to HPLC analysis.

As for HPLC detection and quantification, the chromatographic system consisted of a Perkin-Elmer LC049 isocratic pump (Norwalk, CO, USA) equipped with a Rheodyne model 7125 NS injection valve (50 ml) (Rheodyne, Cotati, CA, USA), a RF-551 fluorescence spectrophotometeric detector (Shimadzu, Kyoto, Japan) equipped with a $150 \mathrm{~W}$ xenon lamp $\left(\lambda_{\text {excitation }}=332 \mathrm{~nm}, \lambda_{\text {emission }}=462\right.$ nm) and a Spectra- Physics SP4290 integrator (San Jose, CA, USA). The analytical column was a Hypersil $^{\mathrm{TM}}$ BDS reversed phase C18 $(15 \mathrm{~cm} \times 4.0 \mathrm{~mm}$ i.d., $3 \mathrm{~mm}$ particles) (Tracer Analytical, Barcelona, Spain). The column was used at room temperature. The mobile phase was made of a mixture of HPLC grade acetonitrile:water:acetic acid (45:54:1), filtered through a $0.22 \mu \mathrm{m}$ filter membrane, degassed and eluted at a flow-rate of $1.0 \mathrm{ml} \mathrm{min}^{-1}$. The eluate was filtered through a $0.45 \mu \mathrm{m}$ microfilter and $50 \mu \mathrm{l}$ were injected for HPLC analysis.

The identity of OTA was confirmed by methyl ester formation according to the method described by Zimmerli \& Dick (1995). Contaminated eluates with OTA concentration $>200 \mathrm{ng} \mathrm{l}^{-1}$ beer were used for this preparation.

\section{DONPrep method for DON determination in beer}

Degassed beer $(20 \mathrm{ml})$ were taken and mixed with acetonitrile $(110 \mathrm{ml})$. This mixture was evaporated using a rotary evaporator at $45 \pm 5^{\circ} \mathrm{C}$ in order to minimize the volume of water on the DONprep column. As DON is soluble in water, a bigger volume of water affect the DON recovery. 
Water $(4 \mathrm{ml})$ containing sodium bicarbonate $(5 \% \mathrm{w} / \mathrm{v})$ was added to recover the extract, which was then submitted to the following purification step. Clean-up of DON extract was performed with a DONPrep column fitted with a 5-ml syringe reservoir. Column conditioning was not necessary and the solubilized extract was directly allowed to pass through the column by gravity. The column was washed with water $(5 \mathrm{ml})$ and was then dried with atmospheric air. DON was eluted with methanol $(2 \mathrm{ml})$ by back flush. The eluted extract was evaporated to dryness at $35 \pm 5^{\circ} \mathrm{C}$ with a rotary evaporator, reconstituted in $1 \mathrm{ml}$ of methanol:water $(10: 90)$ and stored at $-20^{\circ} \mathrm{C}$ prior to $\mathrm{HPLC}$ analysis.

As for HPLC detection and quantification, the chromatographic system consisted of two Waters 515 pumps (Milford, MA, USA), an automatic 717 injector and a 2996 DAD UV detector. The chromatograms were processed using Millenium Empower. The Alltima (100 x $4.6 \mathrm{~mm}$ id, $3 \mu \mathrm{m}$ particles) RP-C 18 column (Alltech, Deerfield, IL, USA) preceded by an OptiGuard precolumn $(10 \times$ $1 \mathrm{~mm}$ i.d., $10 \mu \mathrm{m}$ particles) obtained from Optimize Technology (Oregon City, OR, USA), was thermostatically maintained at $35^{\circ} \mathrm{C}$ by a temperature controller Model 7990 (Jones Chromatography, Hengoed, UK) during HPLC analysis.

The mobile phase was made of a mixture of HPLC grade acetonitrile:water (5:95), filtered through

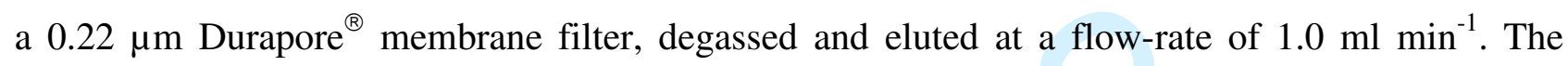
eluate was filtered through a $0.45 \mu \mathrm{m}$ microfilter and $50 \mu \mathrm{l}$ were injected for HPLC analysis.

\section{Validation}

To evaluate the analytical procedures, recovery experiments were performed in triplicate with one type of beer spiked at 50, 150 and $200 \mathrm{ng}$ OTA $1^{-1}$, while DON was added in triplicate samples of three types of beer at 20, 50 and $100 \mu \mathrm{g} \mathrm{l}^{-1}$. The limit of detection (LOD) and limit of quantification (LOQ) of the chromatographic procedures were calculated by the signal-to-noise ratios of 3:1 and 10:1, respectively. The linearity of the detector responses was estimated in experiments with the 
OTA and DON standards. The calibration curves were plotted and their linearity was assessed based on the correlation coefficient (r).

\section{Data handling and statistical analyses}

The calibration curves were calculated using the least-squares method. Experimental results are reported as mean \pm standard deviation $(\mathrm{SD})$. Non-detects were assumed to indicate that the sample contained half the LOD in terms of OTA and DON levels, whereas trace levels were assumed to indicate that the sample contained half the LOD + LOQ (Kroes et al. 2002). For both mycotoxins, the median and range values are given.

The statistical analysis attempted to first determine the presence of significant differences in contamination frequency between conventional and organic samples at levels over the limit of quantification (Chi-square test). Variance analyses were then performed on quantifiable concentrations in order to underline the effect of the mode of production, of the brand and of the batch on the level of contamination. Correlation analysis was used to study the consistency of the association between OTA and DON levels in the tested samples. Independent sample T-test was used to compare the mean OTA in DON positive and negative samples across the two groups of beers. Statement of significance was based on probability of $\mathrm{p}<0.05$.

\section{Results and discussion}

\section{Analytical methods performances}

Chromatograms did not show any impurity interfering with OTA or DON. Regarding OTA analysis, the analytical procedures showed a recovery rate of $91 \%(\mathrm{RSD}=10 \%, \mathrm{n}=9)$ and the respective LOD and LOQ values of 5 and $18 \mathrm{ng}$ OTA $\mathrm{l}^{-1}$ of beer, within the tested range of spiked beer (50-200 ng OTA $\left.1^{-1}\right)$.

As for DON analysis, preliminary results (not published) have shown that the DONPrep column has a maximal capacity of about $1.5 \mu \mathrm{g}$ DON. With the above described procedure, this amount 
corresponds to a concentration of $75 \mu \mathrm{g} \mathrm{DON}{ }^{-1}$ beer. In order to be able to analyze concentrations above $75 \mu \mathrm{g}$ DON $1^{-1}$ beer, we adapted the first step of the method by decreasing the volume of 20 $\mathrm{ml}$ of beer. Thus, only $5 \mathrm{ml}$ of degassed and centrifuged beer were mixed with $30 \mathrm{ml}$ of acetonitrile. Assaying DON recovery experiments in triplicate on three types of beer spiked at 20,50 and $100 \mu \mathrm{g}$ $1^{-1}$, the overall average recovery was $93 \pm 4 \%(\mathrm{n}=27)$. The LOD and LOQ values were 2 and $6 \mu \mathrm{g}$ $\mathrm{DON}^{-1}$ of beer, respectively. Note that the recovery rate at $100 \mu \mathrm{g} \mathrm{DON} 1^{-1}$ estimated at $94 \%$ showed a good precision $(\mathrm{RSD}=5 \%, \mathrm{n}=9$ ). Care must then be taken not to exceed the capacity of the immunoaffinity column.

Occurrence of OTA in organic and conventional beers marketed in Belgium

Table I presents the OTA occurrence in organic and conventional beers produced in Belgium during the 2003-2004 period.

\section{[Insert table I about here]}

OTA was detected in $78 \%$ of conventional samples at a mean level of $25 \pm 38 \mathrm{ng} \mathrm{l}^{-1}$ (range: 19 $198 \mathrm{ng} \mathrm{l}^{-1}$ ). All organic beers were OTA contaminated at a mean level of $182 \pm 275 \mathrm{ng} \mathrm{l}^{-1}$ (range: 18 - $\left.1134 \mathrm{ng} \mathrm{l}^{-1}\right)$. Nevertheless, the magnitude between these means was not statistically significant ( $\mathrm{p}$ $=0.1758$ ). OTA above $200 \mathrm{ng} \mathrm{l}^{-1}$ was quantified in 10 organically produced beers and in none of conventional samples. The statistical analysis showed that the frequencies of quantifiable levels of OTA were significantly higher $(\mathrm{p}<0.0001)$ in contaminated organically produced beers $(95 \%)$ than in their conventional counterparts $(50 \%)$.

Twenty different brands of beers were tested and no significant brand effect $(p=0.2093)$ in the OTA content was observed for all samples combined. In contrast, the variation between different batches was significant $(\mathrm{p}<0.0001)$, showing thus an heterogeneous quality in brewing raw materials (as far as OTA contamination is concerned) within the production of the same brand. This might indicate that different parts of the same stock of raw materials or stocks of various origins 
were used for the preparation of different batches. One must be aware that in stored-grain bulks, "hot spots" of OTA may accidentally occur in a given stock, even if the optimal required conditions for mould development have not been reached. Exceptionally, high concentrations of OTA in a batch of beer may thus occur if highly contaminated raw materials were introduced in the brewing process. This finding corroborates with the temporal fluctuation in OTA contamination in Belgian beers observed by Tangni et al. (2002). One must realize that the mycotoxin contamination status covers a limited period and that year-to-year variations may often occur as specified by Scott \& Kanhere (1995) and Jorgensen (2005).

Numerous surveys have been conducted on OTA contamination in conventionally produced beers across the world. Nakajima et al. (1999) analyzed OTA in 46 European beers and found an average concentration of $11.4 \mathrm{ng} \mathrm{l}^{-1}$ (range: $1.7-66.2 \mathrm{ng} \mathrm{l}^{-1}$ ) in 43 contaminated samples $\left(\mathrm{LOD}=1 \mathrm{ng} \mathrm{l}^{-1}\right.$ ). In Italy, Visconti et al. (2000) analysed the OTA content in 61 samples of 10 domestic and 51 imported beers and found OTA levels ranging from 10 to $135.2 \mathrm{ng} \mathrm{l}^{-1}$ ( $\mathrm{LOD}=10 \mathrm{ng} \mathrm{1^{-1 }}$ ). Beers purchased in Denmark were also investigated for OTA contamination by Jorgensen (1998). All samples $(\mathrm{n}=21)$ contained traces of OTA $\left(>1 \mathrm{ng} \mathrm{l}^{-1}\right)$ with a mean content of $49 \mathrm{ng}^{-1}$ (highest value $=160 \mathrm{ng} \mathrm{l}^{-1}$ ). Similarly, Araguas et al. (2005) studied 21 Spanish beers and found in $67 \%$ of the tested samples a mean of $38 \mathrm{ng} \mathrm{OTA}^{-1}$ (highest value $=205 \mathrm{ng}^{-1}$ ). One must note that these are in accordance with the current study for the conventional type of beer.

So far, a comparison between conventionally (49 samples) and organically (13 samples) produced beers in Belgium has been performed by Tangni et al. (2002). These authors found that the mean OTA content was significantly higher $(\mathrm{p}=0.007)$ in organic $\left(81 \mathrm{ng} \mathrm{l}^{-1}\right)$ than in conventional $(22 \mathrm{ng}$ $\left.1^{-1}\right)$ beers sampled in 1998-1999. In contrast, no significant difference $(\mathrm{p}=0.233)$ was shown for beers collected in 2000-2001, although conventionally produced beers contained higher levels of OTA $\left(49 \mathrm{ng} \mathrm{l}^{-1}\right)$ than organically produced counterparts $\left(29 \mathrm{ng} \mathrm{l}^{-1}\right)$. The highest OTA content (185 ng $1^{-1}$ ) was found in an organically marketed beer. In the present study, attention was paid to the 
sampling procedure by keeping a balanced sample size between organic and conventional groups. We observed that bad cases of contamination occasionally occur in organically produced beers, with concentrations that can be much higher (up to $1134 \mathrm{ng} \mathrm{l}^{-1}$ ) than the limit of $200 \mathrm{ng} \mathrm{l}^{-1}$ (FAO 2004). Independently from the mode of its production, high OTA levels in beer have been seldom presented in the recent literature. In fact, Gumus et al. (2004) analysed 135 Turkish beers and 15 imported beers and found that $28 \%$ of the samples were OTA contaminated at levels ranging from 100 to $8100 \mathrm{ng} \mathrm{l}^{-1}$. It was found that OTA levels were above $3000 \mathrm{ng} \mathrm{l}^{-1}$ in 6 tested samples. So, the risk of highly contaminated batches occurring from time to time should not be underestimated.

\section{Evidence of temporal fluctuation in OTA contamination in beers}

Taking into account the high contamination levels obtained in the above sample, a complementary sampling was performed in March 2005. It was based on the same brands as those analysed in the 2003-2004 period. One bottle (one batch) of each brand was investigated.

Of 10 conventional beers, OTA was detected in 9 samples at mean concentration of $21 \mathrm{ng}^{-1}$ $\left(\right.$ median $=12$; range: $\left.3-67 \mathrm{ng} \mathrm{l}^{-1}\right)$ whereas all organically produced beers (10) were OTA contaminated at the mean level of $75 \mathrm{ng} \mathrm{l}^{-1}$ (median $=54$, range:19 $-158 \mathrm{ng} \mathrm{l}^{-1}$ ). So, none of these

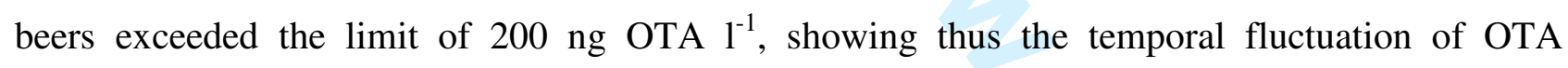
occurrence in beers belonging to the same brands. One should, however, pay attention to the fact that the samples included in this complementary survey were probably produced after the regulation EC No 466/2001 entered in force, which established a maximum level of $3 \mu \mathrm{g}$ OTA kg ${ }^{-1} \mathrm{malt}^{\mathrm{s}}$ (European Commission Regulation 2001). The use of a good quality (as far as OTA contamination is concerned) malt within this legal limit may further avoid the high OTA levels sporadically found in some batches. So, regarding the legal limits, there is a need to continue the work of setting maximum levels for more mycotoxins in more foodstuffs.

Occurrence of DON in organic and conventional beers marketed in Belgium 
Table II shows the results of DON contamination in organically (40) and conventionally (40) produced beers in Belgium.

\section{[Insert table II about here]}

The overall incidences of DON were of 67 and $80 \%$ in conventionally and organically produced beers, respectively. Statistical analysis showed that the frequencies of quantifiable levels of DON were comparable $(\mathrm{p}=0.4586)$ in organic $(25 \%)$ and conventional $(32 \%)$ beers. The respective averages were of 6 and $4 \mu \mathrm{g} \mathrm{DON}^{-1}$ whilst the highest levels were of 22 and $14 \mu \mathrm{g}$ DON $1^{-1}$. The magnitude between these means was not statistically significant $(\mathrm{p}=0.0768)$. Analysis of variance revealed homogeneous DON contamination between different brands whatever the mode of production $(\mathrm{p}=0.8639)$. In contrast, a statistically significant batch effect $(\mathrm{p}<0.0001)$ was noticed within the contaminated samples belonging to the same brand.

As for all samples combined $(n=80)$, the evaluation of DON contamination showed that $74 \%$ of the tested beers were contaminated at a mean level of $5 \mu \mathrm{g}^{-1}$. So far, several reports are available on the extent of DON contamination in beer. Of 54 domestic and imported beers in Korea, Shim et al. (1997) reported an incidence of $26 \%$ for DON contamination ranging from 1 to $23 \mu \mathrm{g} \mathrm{l}^{-1}$. Molto et al. (2000) have found a mean of $14.3 \mu \mathrm{g} \mathrm{l}^{-1}$ (range: $5-221 \mu \mathrm{g} \mathrm{l}^{-1}$ ) in 22 out of 50 Argentinean beers. The European evidence of DON occurrence in beer is backed up by a Canadian survey of 50 beers brewed in Canada or imported from Europe (Scott et al. 1993). This investigation revealed that 29 samples were DON contaminated with an average of $5.4 \mu \mathrm{g}^{-1}$ (range: $0.3-50.3 \mu \mathrm{g} \mathrm{l}^{-1}$ ). More specifically, imported beers from Europe were contaminated at levels ranging from 1.1 to $15.8 \mu \mathrm{g}$ DON $~^{-1}$. Weddeling et al. (1994) reported that all the 18 German beers tested were DON contaminated with an average of $5 \mu \mathrm{g} \mathrm{l}^{-1}$. A much higher contamination level was found in another German study by Niessen et al. (1993). These authors found that 190 out of 196 German beers were contaminated at levels ranging from 148 to $569 \mu \mathrm{g}^{-1}$ (mean $=205 \mu \mathrm{g}^{-1}$ ). These beers were, however, part of a study on gushing and were therefore not randomly selected. Recently, 
contamination data have not shown high levels of DON in beer. Indeed, Schothorst \& Jekel (2003) analysed 51 beer samples collected in the Netherlands and found that DON occurs at a concentration above $25 \mu \mathrm{g} \mathrm{l}^{-1}$ (LOQ value) in only 3 samples, with quantities ranging from 26 to 41 $\mu \mathrm{g} 1^{-1}$. Papadopoulou-Bouraoui et al. (2004) detected DON in $87 \%$ of the analysed beers $(\mathrm{n}=313$, $\left.\mathrm{LOD}=3.7 \mu \mathrm{g} \mathrm{l}^{-1}\right)$ with concentrations ranging from 4.0 to $56.7 \mu \mathrm{g} \mathrm{l}^{-1}$. Most samples $(73 \%) \mathrm{had}$ contamination levels below $20 \mu \mathrm{g} \mathrm{l}^{-1}$. Our results compare well with the low level of DON contamination obtained in these previous studies. We therefore conclude that DON contamination in Belgian beers should not be a major matter of concern. So far, no regulatory guideline for DON contamination in beer is available in terms of safe limit. Indeed, the recent European Commission Regulation No 856/2005 amending the EC regulation No 466/2001 as regarding the Fusarium toxins states only on cereals and cereal based product not including beer (European Commission Regulation 2005).

From an analytical point of view, the present HPLC analytical procedure allows to detect DON in beer at very low levels and can be routinely used to assay the concentrations of DON in beers. Previous studies of DON determination in beer commonly involved gas chromatography (Scott $e t$ al. 1993, Molto et al. 2000, Schothorst \& Jekel 2003) coupled with ECD, FID, MS or MS/MS detectors after derivatisation. Enzyme-linked immunosorbent assay is also used (Niessen et al. 1993, Papadopoulou-Bouraoui et al. 2004), but accurate quantification with this method is often limited, owing to cross reactivities (Schneider et al. 2004).

\section{Co-occurrence of OTA and DON contents in organically and conventionally produced beers}

Based on the DON detection limit, two subgroups of DON-positive (levels $\geq$ LOD, $n=59$ ) and DON-negative (level < LOD, $\mathrm{n}=21$ ) were considered.

The mean DON in the positive group $\left(7 \pm 4 \mu \mathrm{g} \mathrm{l}^{-1}\right)$ was obviously significantly higher $(\mathrm{p}<0001)$ than the level of contamination in the negative group. The respective concentrations of $8 \pm 6$ and 5 
$\pm 2 \mu \mathrm{g} \mathrm{DON}^{-1}$ were found in conventional and organic positive sub groups. In contrast, the mean OTA $\left(107 \pm 230 \mathrm{ng}^{-1}\right)$ in the DON-positive group was comparable $(\mathrm{p}=0.085)$ to the mean OTA $\left(48 \pm 71 \mathrm{ng} \mathrm{l}^{-1}\right)$ found in the DON-negative group. The same trend was separately observed either

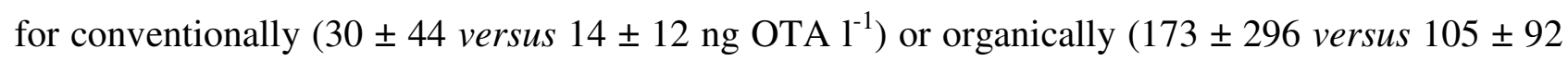
ng OTA $1^{-1}$ ) produced beers, highlighting that a real significant co-occurrence of both toxins was not found for the tested beers, whatever their mode of production was. Moreover, non-significant correlation coefficients were derived between OTA and DON levels for either conventional $(\mathrm{r}=$ $+0.125, \mathrm{p}=0.441)$ or organic $(\mathrm{r}=+0.091, \mathrm{p}=0.576)$ group of beers.

If contaminated raw materials are used during the brewing process, beer can be contaminated by all key cereal mycotoxins, except perhaps citrinin, which does not seem to survive the mashing step (Galvano et al. 2005). Zearalenone and OTA or aflatoxin $\mathrm{B}_{1}$ and OTA coexisted in beers analysed in Japan (Nakajima et al. 1999) and in South-Africa (Odhav \& Neckair 2002). Co-occurrence of trichothecenes such as DON, nivalenol, diacetoxyscirpenol, 3-acetyl deoxynivalenol, 15-acetyl deoxynivalenol and neosolaniol have been found in Canada (Scott et al. 1993) as well as in Argentina (Molto et al. 2000). Note that the simultaneous occurrence of two or more toxins in cereals has frequently been documented in the literature, e.g. barley, malt, maize and wheat contaminated with DON, nivalenol and zearalenone (Lee et al. 1986, Park et al. 1992, Tanaka et al. 2000), maize contaminated with fumonisin B1, DON, T-2 toxin, nivalenol and zearalenone (Ali et al. 1998), wheat contaminated with DON and OTA (Birzele et al. 2000) and barley contaminated with OTA and DON (Olsson et al. 2002). These findings highlight the problems associated with ingestion of multiple toxins that may have an interactive effect on the health of the consumers.

Assessment of the contribution of beer to the OTA and DON exposure for the consumers

In recent years, thorough risk assessments of the trichothecenes and of OTA established a provisional maximum tolerable daily intake of $1 \mu \mathrm{g} \mathrm{DON} \mathrm{kg}^{-1}$ bw and a tolerable daily intake (TDI) 
of $5 \mathrm{ng}$ OTA kg ${ }^{-1}$ bw (FAO/WHO 2001). Considering a daily intake of 0.31 beer per capita in Belgium (CBB 2004) and the mean levels of DON and OTA found in the present study, beer consumption contributes simultaneously to $3 \%$ and $10 \%$ of the TDI of DON and OTA for an adult of $60 \mathrm{~kg}$. We conclude that moderate daily intakes of DON and OTA are provided through beer consumption in Belgium. Beer consumption should thus not lead to acute toxic reactions linked to DON and OTA. It should however be included in calculations of total exposure to DON and OTA, together with other sources of cereals and other foodstuffs, which undoubtedly provide these mycotoxins as well. So far, the effects of a chronic exposure to low levels of these mycotoxins (long-term exposure) are not yet known (Gudmestad et al. 1997) and the combined effects of mycotoxins may increase their toxic effects. As an example, Foster et al. (1986) showed that DON in naturally contaminated feed has a higher toxicity in comparison to pure DON, suggesting that cocontamination with some unknown toxic metabolite or co-occurrence with a non-toxic compound enhances the toxicity of DON. Moreover, it is noticed that DON belongs to the group of several trichothecenes with a common basic chemical structure, which are produced by Fusarium fungi (e.g. T-2 Toxin, HT-2 toxin, nivalenol). These mycotoxins may share common mechanisms of action, which may lead to significant interactions. For all these reasons, the TDI for DON is determined only temporarily (FAO/WHO 2001). Generally, the problem of multi-contamination should not be underestimated.

In conclusion, the present study has further warranted the occurrence of low levels of OTA in beer. OTA was detected in about $90 \%$ of the samples, but the levels were often far below the limit of 200 ng OTA $1^{-1}$. A few batches from organic beers were found to be much more contaminated, at levels exceeding this limit. The situation appeared to have improved from 2003-2004 to 2005 since none of the sample collected in 2005 exceeded the limit of $200 \mathrm{ng}$ OTA ${ }^{-1}$. This improvement may reflect the newly imposed controls on malt. Occurrence of DON in beers should not be a major cause for concern since this toxin was found at low levels in a limited number of beers. 


\section{Acknowledgments}

This research project has been carried out within the framework of the Scientific support plan for a sustainable development policy (SPSD II) Part I "Sustainable production and consumption patterns" (Project CP/30 Mycotoxin contamination of regular and organic foodstuffs). The financial support of the Belgian Federal Science Policy Office is acknowledged here. F. Van Hove also acknowledges the financial support of the BCCM Research Programme (contract BCCM C3/10/003) from the same Office.

\section{References}

Ali N, Sardjono-Yamashita A, Yoshizawa T. 1998. Natural co-occurrence of aflatoxins and Fusarium mycotoxins (fumonisins, deoxynivalenol, nivalenol and zearalenone) in corn from Indonesia. Food Additives and Contaminants 15:377-384.

Araguas C, Gonzalez-Penas E, Lopez de Cerain A. 2005. Study on ochratoxin A in cereal-derived products from Spain. Food Chemistry 92:459-464.

Baxter ED. 1996. The fate of ochratoxin A during malting and brewing. Food Additives and Contaminants 13 suppl.:23-24.

Baxter DE, Slaiding IR, Kelly B. 2001. Behavior of ochratoxin A in Brewing. Journal of the American Society of Brewing Chemists 59:98-100.

Birzele B, Prange A, Kramer J. 2000. Deoxynivalenol and ochratoxin A in German wheat and changes of level in relation to storage parameters. Food additives and contaminants 17:1027-1035.

Boeira LS, Bryce JH, Steward GG, Flannigan B. 2000. The effect of combinations of Fusarium mycotoxins (deoxynivalenol, zearalenone and fumonisin B1) on growth of brewing yeasts. Journal of Applied Microbiology 88:388-403. 
CBB (Belgian Brewery Confederation). 2004. Aperçu du secteur de la Braserie Belge, Statistiquesl'année 2004. Source Banque Nationale et Brasseurs Belges. Available at: [http://www.beerparadise.be/fr/pdf/tabel\%202\%20frans.jpg].

European Union, European Commission Regulation No 466/2001 of 8 March 2001 setting maximum levels for certain contaminants in foodstuffs. Official Journal of the European Communities L 77 (16.3.2001), 13p.

European Union, European Commission Regulation $N^{\circ} 856 / 2005$ amending EC Regulation No 466/2001 as regards Fusarium -toxins setting maximum levels for certain contaminants in foodstuffs Official Journal of the European Communities L143 (6.6.2005), 8p.

FAO. 2004. Food and Nutrition Paper 81: Worldwide regulations for mycotoxins in food and feed in 2003. 183 p. Available at : ftp://ftp.fao.org/docrep/fao/007/y5499f/y5499f00.pdf.

FAO/WHO. 2001. Joint Food and Agriculture Organization/World Health Organization. (FAO/WHO) Expert Committee on Food Additives, fifty-sixth meeting. Geneva, 6-15 February 2001, pp1-33. Online available at: http://www.fao.org/es/ESN/ Jecfa /jecfa56.pdf or at: http://www.inchem.org/documents/jecfa/jecmono/v47je01.htm.

Finamore A, Britti MS, Roselli M, Bellovino D, Gaetani S, Mengheri E. 2004. Novel approach for food evaluation. Results of a pilot experiment to evaluate organic and conventional foods. Journal of Agriculture and Food Chemistry 52:7425-7431.

Foster BC, Trenholm HL, Friend DW, Thompson BK, Hartin KE. 1986. Evaluation of different sources of deoxynivalenol (vomitoxin) fed to swine. Canadian Journal of Animal Science 66:1149-1154.

Galvano F, Titieni A, Piva G, Pietri A. 2005. Mycotoxins in the human food chain. In: D. Diaz, Editor. The mycotoxin Blue Book. Nottingham (England): Nottingham University Press. pp $187-224$. 
Kroes R, Müller D, Lambe J, Löwik MRH, Van Klaveren J, Kleiner J, Massey R, Mayer S, Urieta I, Verger P, Visconti A. 2002. Assessment of intake from the diet. Food and Chemical Toxicology 40:327-385.

Lee U, Jang H, Tanaka T, Hasegawa A, Oh Y, Cho C, Sugiura Y, Ueno Y. 1986. Further survey on the Fusarium mycotoxins in Korean cereals. Food Additives and Contaminants 3:253-261.

MacDonald S, Wilson P, Barnes K, Damant A, Massey R, Mortby E, Shepherd MJ. 1999. Ochratoxin A in dried vine fruit: method development and survey. Food Additives and Contaminants 16:253-260.

Macdonald S, Prickett TJ, Wildey KB, Chan D. 2004. Survey of ochratoxin A and deoxynivalenol in stored grains from the 1999 harvest in the UK. Food Additives and Contaminants 21:172181.

Magkos F, Arvaniti F, Zampelas A. 2003. Putting the safety of organic food into perspective. Nutrition Research Review 16:211-222. 
Molto G, Samar MM, Resnik S, Martinez EJ, Pacin A. 2000. Occurrence of trichothecenes in Argentinean beer: a preliminary exposure assessment. Food Additives and Contaminants 17: 809-813.

Moss MO. 1998. Recent studies of mycotoxins. Symposium series (Society for Applied Microbiology) 27:62S-76S.

Nakajima M, Tsubouchi H, Miyabe M. 1999. A survey of ochratoxin A and aflatoxins in domestic and imported beers in Japan by immunoaffinity and liquid chromatography. Journal of AOAC International 82:897-902.

Niessen L, Donhauser S. 1993. Fate of deoxynivalenol in the process of brewing and its prevalence in commercial beer. In K. Scudamore, editor. Occurrence and Significance of Mycotoxins. Central Science Laboratory, Slough, 203-207.

Niessen L, Boehm-Schraml M, Vogel H, Donhauser S. 1993. Deoxynivalenol in commercial beer screening for the toxin with an indirect competitive ELISA. Mycotoxin Research 9:99-109.

Odhav B, Neckair V. 2002. Mycotoxins in South African traditionally brewed beers. Food Additives and Contaminants 19:55-61.

Olsson J, Börjesson T, Lundstedt T, Schnürer J. 2002. Detection and quantification of ochratoxin A and deoxynivalenol in barley grains by GC-MS and electronic nose. International Journal of Food Microbiology 72:203-214.

Otteneder H, Majerus P. 2001. Ochratoxin A (OTA) in coffee: nation-wide evaluation of data collected by German Food Control 1995-1999. Food Additives and Contaminants 18:431435.

Papadopoulou-Bouraoui A, Vrabcheva T, Valzacchi S, Stroka J, Anklam E. 2004. Screening survey of deoxynivalenol in beer from the European market by an enzyme-linked immunosorbent assay. Food Additives and Contaminants 21:607-617. 
Park KJ, Park AR, Lee YW. 1992. Natural occurrence of Fusarium mycotoxins of the 1990 barley crop in Korea. Food Additives and Contaminants 9:639-645.

Pettersson H. 1998. Intercomparison of trichothecene analysis and feasibility to produce certified calibrants and reference material. European Commission. BCR information reference materials. Brussels - Luxembourg, 143 p.

Pitt JI. 1987. Penicillium viridicatum, Penicillium verrucosum, and production of ochratoxin A. Applied and Environmental Microbiology 53:266-269.

Pussemier L, Larondelle Y, Van Peteghem C, Huyghebaert A. 2006. Chemical safety of conventionally and organically produced foodstuffs: a tentative comparison under Belgian conditions. Food Control 17:14-21.

Samson RA, Houbraken JAMP, Kuijpers AFA, Frank, JM, Frisvad JC. 2004. New ochratoxin A or sclerotium producing species in Aspergillus section Nigri. Studies in Mycology 50:45-61.

Schneider E, Curtui V, Seidler C, Dietrich R, Usleber E, Martlbauer E. 2004. Rapid methods for deoxynivalenol and other trichothecenes. Toxicology Letters 153:113-121.

Schothorst RC, Jekel AA. 2003. Determination of trichothecenes in beer by capillary gas chromatography with flame ionisation detection. Food Chemistry 82:475-479.

Scott PM, Kanhere SR, Weber D. 1993. Analysis of Canadian and imported beers for Fusarium mycotoxins by gas chromatography-mass spectrometry. Food Additives and Contaminants 10:381-389.

Scott PM, Kanhere SR. 1995. Determination of ochratoxin A in beer. Food Additives and Contaminants 12:591-598. 
Serra R, Braga A, Venâncio A. 2005. Mycotoxin-producing and other fungi isolated from grapes for wine production, with particular emphasis on ochratoxin A. Research in Microbiology 156:515-521.

Shim WB, Kim JC, Seo JA, Lee YW. 1997. Natural occurrence of trichothecenes and zearalenone in Korean and imported beers. Food Additives and Contaminants 14:1-5.

Tanaka T, Yoneda A, Inoue S, Sugura Y, Ueno Y. 2000. Simultaneous determination of trichothecene mycotoxins and zearalenone in cereals by gas chromatography-mass spectrometry. Journal of Chromatography A 882:23-28.

Tangni EK, Ponchaut S, Maudoux M, Rozenberg R, Larondelle Y. 2002. Ochratoxin A in domestic and imported beers in Belgium: occurrence and exposure assessment. Food Additives and Contaminants 19:1169-1179.

Thirumala-Devi K, Mayo MA, Reddy G, Tangni, EK, Larondelle Y, Reddy DV. 2001. Occurrence of ochratoxin A in black pepper, coriander, ginger and turmeric in India. Food Additives and Contaminants 18: 830-835.

Visconti A, Pascale M, Centonze G. 2000. Determination of ochratoxin A in domestic and imported beers in Italy by immunoaffinity clean-up and liquid chromatography. Journal of Chromatography A 888:321-326.

Weddeling KH, Bäbler MS, Doerk H, Baron G. 1994. Oriented tests for the application of the enzymimmunological process for evidencing deoxynivalenol, ochratoxin A and zearalenone in brewing barley, malt and beer. Monatsschrift fürBrauwissenschaft 47:94-98.

Wood GM, Entwisle C, Farnell PJ, Patel S, Boenke A. 1996. The certification of the ochratoxin A mass fraction of two wheat reference materials (CRMs $471 \& 472$ ). European Commission BCR information. Brussels-Luxembourg. 58 p. 
Zimmerli B, Dick R. 1995. Determination of ochratoxin A at the ppt level in human blood, serum, milk and some foodstuffs by high-performance liquid chromatography with enhanced fluorescence detection and immunoaffinity column cleanup: methodology and Swiss data. Journal of Chromatography B: Biomedical Applications 666:85-99. 


\section{List of tables}

Table I. Occurrence of OTA in organic and conventional beers sold on the Belgian market (period $2003-2004$.

Table II. Occurrence of DON in organic and conventional beers sold on the Belgian market (period 2003- 2004). 
3

Table I. Occurrence of OTA in organic and conventional beers sold on the Belgian market (period

$$
2003 \text { - 2004). }
$$

\begin{tabular}{|c|c|c|c|}
\hline Occurrence & Conventional & Organic & Total \\
\hline Number of samples & 40 & 40 & 80 \\
\hline n.d. ${ }^{\text {a }}$ & $9(22 \%)$ & 0 & $9(11 \%)$ \\
\hline $\operatorname{trace}^{\mathrm{b}}$ & $11(28 \%)$ & $2(5 \%)$ & $13(16 \%)$ \\
\hline LOQ - $100 n g \mathrm{l}^{-1}$ & $18(45 \%)$ & $22(55 \%)$ & $40(50 \%)$ \\
\hline $101-200 \mathrm{ng} \mathrm{l}^{-1}$ & $2(5 \%)$ & $6(15 \%)$ & $8(10 \%)$ \\
\hline $200.1-1200 \mathrm{ng} \mathrm{l}^{-1}$ & 0 & $10(25 \%)$ & $10(13 \%)$ \\
\hline Incidence & $78 \%$ & $100 \%$ & $89 \%$ \\
\hline \multicolumn{4}{|c|}{ Levels of contamination $\left(\mathrm{ng} \mathrm{l}^{-1}\right)$} \\
\hline $\operatorname{Mean}^{\mathrm{c}} \pm \mathrm{SD}$ & $25 \pm 38$ & $182 \pm 275$ & $103 \pm 162$ \\
\hline Median $^{c}$ & 15 & 45 & 29 \\
\hline Range $^{\mathrm{d}}$ & $19-198$ & $18-1134$ & $18-1134$ \\
\hline
\end{tabular}

${ }^{\mathrm{a}}:$ n.d., not detected (OTA concentration in sample $<5 \mathrm{ng} \mathrm{l}^{-1}$ )

${ }^{b}$ : traces means that the concentration of OTA is between the limit of detection (LOD $=5 \mathrm{ng} \mathrm{l}^{-1}$ ) and the limit of quantification $\left(\mathrm{LOQ}=18 \mathrm{ng}^{-1}\right)$

${ }^{c}$ : mean and median are computed assuming that non-detected samples contain half the LOD while samples with traces levels of OTA contain half the LOD + LOQ

${ }^{\mathrm{d}}$ : range of samples with OTA contents $\geq \mathrm{LOQ}$ 
Table II. Occurrence of DON in organic and conventional beers sold on the Belgian market (period 2003- 2004).

\begin{tabular}{|c|c|c|c|}
\hline Occurrence & Conventional & Organic & Total \\
\hline Number of samples & 40 & 40 & 80 \\
\hline n.d. ${ }^{\mathrm{a}}$ & $13(33 \%)$ & $8(20 \%)$ & $21(26 \%)$ \\
\hline $\operatorname{trace}^{\mathrm{b}}$ & $14(35 \%)$ & $22(55 \%)$ & $36(45 \%)$ \\
\hline LOQ - $10 \mu \mathrm{g} \mathrm{l^{-1 }}$ & $5(12 \%)$ & $8(20 \%)$ & $13(16 \%)$ \\
\hline $10-20 \mu \mathrm{g} \mathrm{l}^{-1}$ & $6(15 \%)$ & $2(5 \%)$ & $8(10 \%)$ \\
\hline $20-30 \mu \mathrm{g} \mathrm{l}^{-1}$ & $2(5 \%)$ & 0 & $2(3 \%)$ \\
\hline$>30 \mu \mathrm{g} \mathrm{l}^{-1}$ & 0 & 0 & 0 \\
\hline Incidence & $67 \%$ & $80 \%$ & $74 \%$ \\
\hline \multicolumn{4}{|c|}{ Levels of contamination $\left(\mu \mathrm{g} \mathrm{I}^{-1}\right)$} \\
\hline $\operatorname{Mean}^{c} \pm$ SD & $6 \pm 6$ & $4 \pm 3$ & $5 \pm 4$ \\
\hline Median $^{c}$ & 4 & 4 & 4 \\
\hline Range $^{\mathrm{d}}$ & $6-22$ & $6-14$ & $6-22$ \\
\hline
\end{tabular}

${ }^{a}:$ n.d., not detected (DON concentration in sample $<2 \mu \mathrm{g} 1^{-1}$ )

${ }^{\mathrm{b}}$ : traces means that the concentration of DON is between the limit of detection $\left(\mathrm{LOD}=2 \mu \mathrm{g} 1^{-1}\right.$ ) and the limit of quantification ( $\mathrm{LOQ}=6 \mu \mathrm{g}^{-1}$ )

c: mean and median are computed assuming that non-detected samples contain half the LOD while samples with traces levels of DON contain half the LOD + LOQ

${ }^{\mathrm{d}}$ : range of samples with DON contents $\geq$ LOQ 